\title{
Ontogenetic and sexual variation in the sagitta otolith of Menticirrhus americanus (Teleostei; Sciaenidae) (Linnaeus, 1758) in a subtropical environment
}

\author{
Barbara Maichak de Carvalho ${ }^{1}$; Alejandra Vanina Volpedo ${ }^{2,3}$ \& Luís Fernando Fávaro ${ }^{4}$ \\ 1 Universidade Federal do Paraná (UFPR), Departamento de Engenharia Ambiental (DEA), Programa de Pós-Graduação em Engenharia \\ Ambiental. Curitiba, PR, Brasil. ORCID: http://orcid.org/0000-0001-7958-427X. E-mail: bmaicarvalho@gmail.com \\ 2 Universidad de Buenos Aires (UBA), Facultad de Ciencias Veterinarias (FVET), Centro de Estudios Transdisciplinarios del Agua (CETA). \\ Buenos Aires, Argentina. ORCID: http://orcid.org/0000-0003-3321-311X. E-mail: avolpedo@gmail.com \\ ${ }^{3}$ Consejo Nacional de Investigaciones Científicas y Técnicas (CONICET), Instituto de Investigaciones en Producción Animal (INPA). Buenos Aires, Argentina. \\ ${ }^{4}$ Universidade Federal do Paraná (UFPR), Departamento de Biologia Celular (DBC), Laboratório de Reprodução e Comunidade de Peixes (LRCP). \\ Curitiba, PR, Brasil. ORCID: http://orcid.org/0000-0001-7306-5858. E-mail: favaroluis@gmail.com
}

\begin{abstract}
This study aimed to verify variations in the form of the sagitta otolith of Menticirrhus americanus as to their ontogeny, sex and stage of such structure. Ontogenetically were found significant differences $(p<0.05)$ for all shape indices (aspect ratios, shape factor, rectangularity, ellipticity, relative surface of sulcus acusticus) and also in the wavelet of the otolith. The CVA presented a $98.6 \%$ correct reclassification of the otolith between interval class. Sexual variations were found in the wavelet and in the relative surface of sulcus acusticus index. Between adult females and young females, differences were not detected in the wavelet and rectangularity, but significant differences were found in all other shape indices. The CVA presented a $79.6 \%$ correct reclassification of the otolith of the sexes and stages of life sampled. Young females and adults females showed highest correct percentage of classification. The results of this study demonstrate for the first time the influence of the ontogenetic variation and sexual in the form of the otoliths.
\end{abstract}

Key-Words. Dimorphism; Otolith; Shape indices; Stage of life; Wavelet.

\section{INTRODUCTION}

Otoliths are calcium carbonate precipitated primarily as aragonite structures. Present in the inner ear in three pairs: sagittae, asteriscus and lapillus (Popper et al., 2005). Their morphological patterns make them an important tool (Volpedo \& Echeverría, 2000; Volpedo et al., 2017). In this way, they are useful in studies of trophic ecology of ichthyophagous (Bustos et al., 2012; Miotto et al., 2017), in the identification of fish stocks through morphology and morphometry (Avigliano et al., 2015; Zischke et al., 2016), habitat use (Avigliano et al., 2014; Carvalho et al., 2017), connectivity between populations (Teimori et al., 2012; Tanner et al., 2013; Davoren \& Halden, 2014) and age and growth (Vaz-dos-Santos \& Rossi-Wongtschwski, 2007; Egbert \& Rulifson, 2017).

Although otoliths have interspecific patterns among species, some morphological changes may occur influenced by various physiological or external factors (Volpedo \& Echeverría, 1999).
Reproduction is one of the physiological factors that may influence the morphology of otoliths (Tombari et al., 2005; Carvalho \& Corrêa, 2014). Some species of the family Atheronipsidae after the onset of the reproductive process develop a dorsal depression in the sagitta otolith (Tombari et al., 2005; Carvalho \& Corrêa, 2014). In addition to morphological differences between young and adult, it is also possible to identify variations in otolith growth rates before and after the first maturity (Carvalho et al., 2015). Food availability may also differentiate otolith morphology among species (Gagliano \& McCormick, 2004).

Also, in some species, the biomineralization of otoliths causes morphological and morphometric variations between the sexes (Légua et al., 2013; Mille et al., 2015; Bose et al., 2016). Different sex growth rates may also influence the morphological and morphometric patterns of otoliths; this change was observed in Micropogonias furnieri (Bervian et al., 2006) and Anchoa tricolor (Carvalho et al., 2015) on the subtropical Southwestern Atlantic Ocean. 
In addition to the physiological factors cited above, environmental factors may influence the morphology and morphometry of otoliths. The depth is related to alterations in the sulcus acusticus area allowing a greater sound perception (Torres et al., 2000; Cruz \& Lombarte, 2004). Salinity influences the otolith shape of Odontesthes bonariensis and it is possible to identify processes of environmental salinization or habitat change (Avigliano et al., 2012; Avigliano et al., 2014), the same process of habitat change was identified for Anguilla anguilla (Capoccioni et al., 2011). Thermal amplitudes in water bodies also modify the shape of otoliths in populations exposed to this factor (Lombarte \& Lleonart, 1993; Légua et al., 2013).

Some methods can be used to describe the morphology and morphometry of otoliths (Lombarte \& Tuset, 2015). Shape indeces contribute in understanding the morphometric relationships between fish and otoliths (Volpedo \& Echeverría, 1999; Tuset et al., 2003; Carvalho et al., 2015). The evaluation of the contour of the otoliths can be done through different methods such as: polar coordinates (Lombarte \& Tuset, 2015), landmarks (Monteiro et al., 2005; Carvalho et al., 2015), fourier harmonics (Libungan et al., 2015; Bose et al., 2016) and wavelets (Sadighzadeh et al., 2014; Tuset et al., 2015). According Sadighzadeh et al. (2012), the fourier harmonics present better results in phylogenetically distant species while wavelets are more efficient in the differentiation of nearby species and identify intraspecific variations.

The morphology and morphometry of the sagitta otolith of sciaenids has been described by several studies (Corrêa \& Vianna, 1992; Volpedo \& Echeverría, 1999, 2000; Waessle et al., 2003; Siliprandi et al., 2014). Menticirrhus americanus is a species belonging to the family Sciaenidae widely distributed in the Southwestern Atlantic Ocean between latitude $41^{\circ} \mathrm{N}$ and $51^{\circ} \mathrm{S}$ (Chao et al., 2015). It is a demersal species with benthophagous habits (Froese \& Paully, 2017; Haluch et al., 2009). Previous studies made brief morphological and morphometric descriptions of the sagitta otolith of Menticirrhus americanus (Volpedo \& Echeverría, 2000; Siliprandi et al., 2014; Volpedo et al., 2018). But these studies not testing the ontogenetic, sexual and life stage variations in the shape of the otolith. Due to this lack of knowledge in this study we will verify possible ontogenetic, sexual and life stage variations (young females and small adult females) in the shape of otolith sagitta de Menticirrhus americanus.

\section{MATERIAL AND METHODS}

\section{Area of study and sampling}

Bimonthly samplings were performed between August 2015 and February 2016 in two beaches. Initially, in an internal estuarine beach (P1) using gillnets of different mesh sizes $(2.5,4$ and $5 \mathrm{~cm})$ and was also used to obtain copies of fishing with hook. On the beach outside the estuary (P2), specimens of artisanal fishing using gillnets of different mesh sizes $(6,7$ and $9 \mathrm{~cm})$. Samplings were carried out at the mouth of an estuary and an adjacent beach in the subtropical Southwestern Atlantic Ocean of Brazil $\left(25^{\circ} 28^{\prime}-25^{\circ} 36^{\prime} \mathrm{S}, 48^{\circ} 20^{\prime}-48^{\circ} 28^{\prime} \mathrm{W}\right.$, Paranaguá Bay, Fig. 1), considered a transition region between tropical and temperate climate (Spalding et al., 2007).

The specimens caught were identified, measured for total length and total weight ( $T L$, in millimeters and TW, in grams, respectively) and separated into five interval classes (110-150; 160-200; 210-250; 260-300; 310-350 mm). Sagitta otoliths were extracted. Gonads were removed, the sex and maturity stage were determined by microscopic analysis according to the procedure described in Possamai \& Fávaro (2015).

\section{Morphometry of otolith}

Only the right otolith was photographed, and the morphology of the internal face was classified according to Tuset et al. (2008). Measurements of the right otoliths were taken using the ImageJ program, namely: length $(\mathrm{OL}$, greater longitudinal distance in $\mathrm{mm}$ ) and height $(\mathrm{OH}$, greater perpendicular distance in $\mathrm{mm})$ and area $(\mathrm{A})$ of the otolith, area $\left(\mathrm{mm}^{2}\right)$ of the sulcus acusticus (AS) and otolith perimeter ( $\mathrm{P}$, in $\mathrm{mm}$ ) (Fig. 2).

In order to verify the ontogenetic, sexual and in the stages of life variations, the following shape indices were applied as described: OL/TL and $\mathrm{OH} / \mathrm{OL} \%$ Aspect Ratios (Volpedo \& Echeverría, 2003), Form Factor $\left[F F=\left(4 \pi^{*} A\right) P^{-1}\right]$, Rectangularity $[R c=(A /(O L \times O H))$, Ellipticity $[\mathrm{E}=(\mathrm{OL}-\mathrm{OH} / \mathrm{OL}+\mathrm{OH})]$ (Tuset et al., 2003) and Relative surface of the sulcus acusticus [Rss $=A S / A$ ] (Lombarte, 1992).

\section{Contour of otolith}

The otolith contour reconstruction was done using the wavelets. Wavelets are the result of the expansion of a signal in a family of functions that represent the dilations and translations of a mother function (Mallat, 1991): $\Psi_{s}(x)=1 / s \Psi(\varphi / s)$, where: $\Psi$ is the function with local support in a limited amplitude on the abscissa axis; $\varphi$ is the lower pitch filter; $s$ is the scale parameter. The wavelet analysis allows to identify morphological similarities and/or differences as well as at which position of the otolith they are found, since the functions are elaborated from 512 Cartesian coordinates projected at points equidistant along the otolith (Lombarte \& Tuset, 2015). The wavelet acquisition was performed as described by Parisi-Baradad et al. (2010) in site AFORO (http://isis.cmima.csic.es/aforo/index.jsp).

\section{Statistical analysis}

The data (shape indices and wavelet) did not meet the assumptions of parametric analysis (Shapiro-Wilk; $p<0.05$ and Bartlett, $p<0.05$ ). In this way, the KruskalWallis test was applied to check for differences in shape indices between class intervals and the Conover post- 


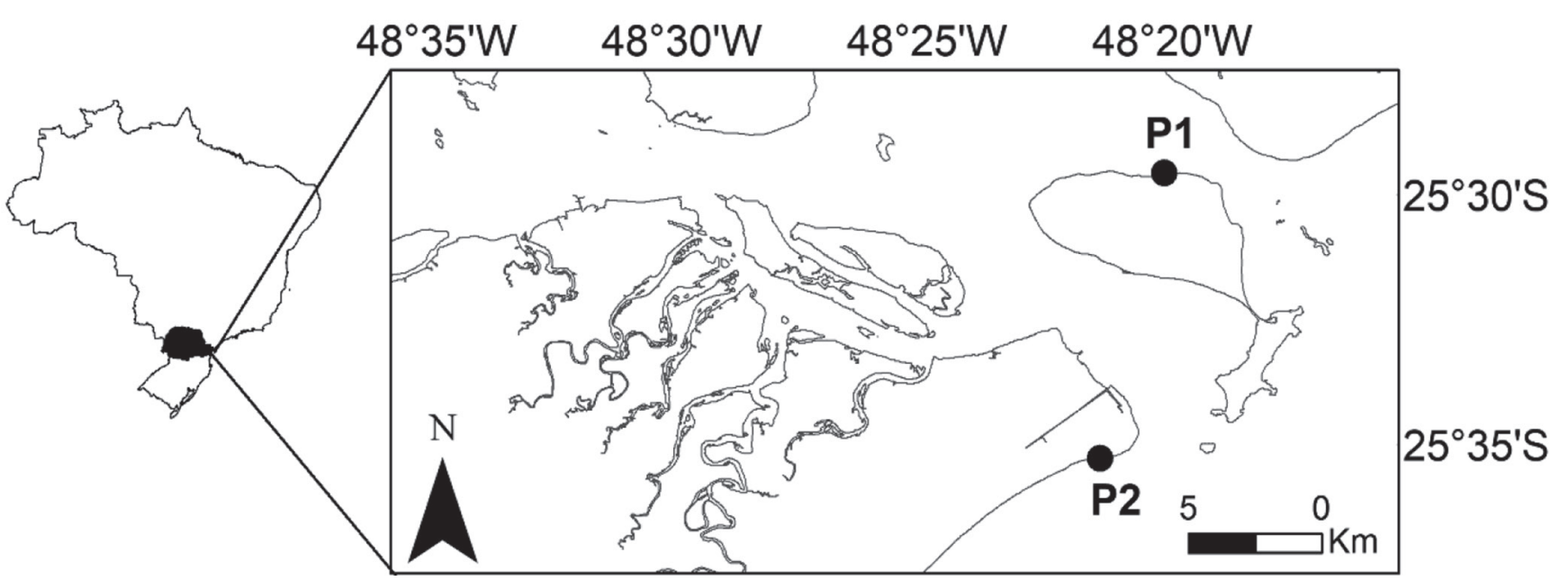

Figure 1. Sampling sites of Menticirrhus americanus in estuarine areas (P1) and a beach adjacent (P2) to the estuary in the Subtropical Southwestern Atlantic.
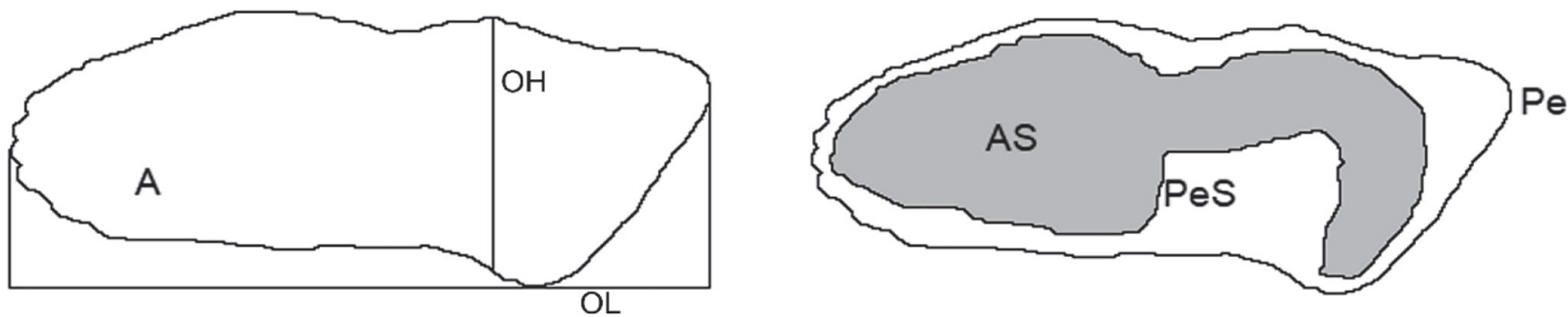

Figure 2. Scheme of linear morphometry applied to the right otolith of Menticirrhus americanus collected in a subtropical environment: $0 \mathrm{~L}=$ maximum longitudinal length, $\mathrm{OH}=$ maximum perpendicular height, $\mathrm{A}=$ area of the otolith and $\mathrm{AS}=$ area of the sulcus acusticus, $\mathrm{Pe}=$ perimeter of the otolith and $\mathrm{PeS}=$ perimeter of the sulcus acusticus.

hoc test was applied to identify between which class intervals the indices varied significantly (Pohlert, 2016).

In order to test the sexual differences and in the life stages (young and young females) among the indexes of form were selected specimens collected exclusively in P1. Specimens of similar lengths of females were selected $(n=30 ;$ TL mean $=230 \pm 12 \mathrm{~mm})$ and adults males ( $\mathrm{n}=30 ; \mathrm{TL}$ mean $=222 \pm 16 \mathrm{~mm}$ ), young females ( $\mathrm{n}=29$; TL mean $=144 \pm 16 \mathrm{~mm}$ ) and small young females $(n=29 ;$ TL mean $=175 \pm 16 \mathrm{~mm}$ ) this similar size selection between groups is to avoid the effect of allometry on the data. The Wilcoxon Mann-Whitney test was used to test possible variations in the shape indices between males and females and between young females and small young females.

The Permutational Analysis of Variance (PERMANOVA) was used to identify variations in the contour between

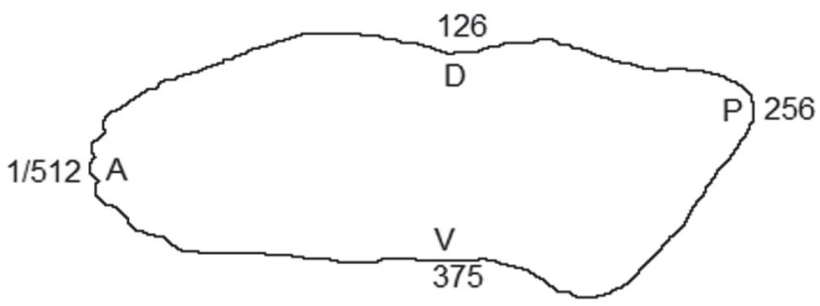

Figure 3. Otolith contour using 512 equidistant point in the otolith the Menticirrhus americanus para a in a subtropical environment: $D=$ dorsal region of otolith, $V=$ ventral region of otolith, $A=$ anterior region of otolith and $\mathrm{P}=$ posterior region of otolith. class intervals. The Bonferroni test was used to identify between which intervals the interactions were significant ( $p<0.005$ ). A principal component analysis (PCA) was used to verify the shape variation between the class intervals of the otoliths obtained. Later, with the main components (PCs), a canonical variable analysis (CVA) was performed to verify the percentage of correct reclassification of otoliths between class intervals (Linde et al., 2004).

A principal component analysis (PCA) was also performed to identify sexual variations and life stages in wavelets obtained from selected otoliths. The CVA to verify the percentage of correct reclassification of the otoliths between the sexes and between young females and young adults with com PCs. The Bonferroni test was used to verify between which parameters these interactions were significant $(p<0.05)$. Statistical analyses were performed using the R software and Past (Hammer et al., 2001).

\section{RESULTS}

A total of 291 specimens of $M$. americanus (TL range: 120 and $345 \mathrm{~mm}$; TW range: 15.33 and $291 \mathrm{~g}$ ) were analyzed, which were distributed in five length class intervals to describe the ontogeny (Fig. 4). Were used for sexual variation a total 60 specimens of which 30 females ( $T L$ mean $=230 \pm 12 \mathrm{~mm}$ ) and 30 males $(T L$ mean $=222 \pm 16 \mathrm{~mm})$. Also, were used for life stage 


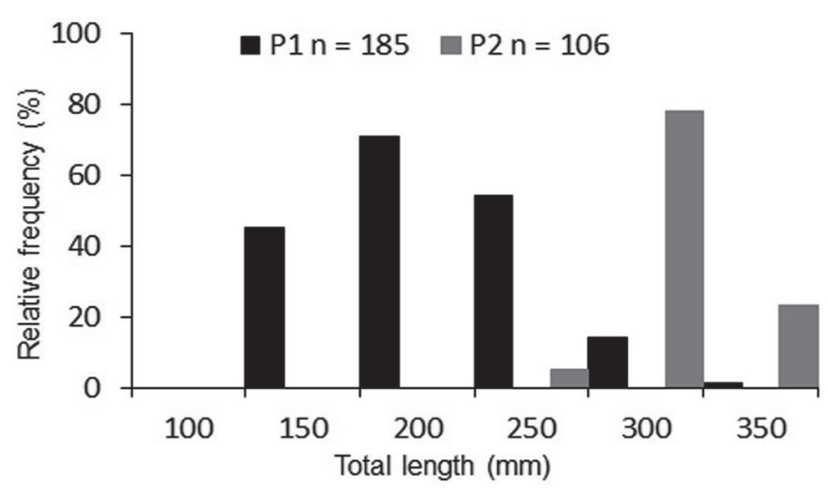

Figure 4. Frequency distribution of the total length $(\mathrm{mm})$ of the Menticirrhus americanus in two environments in the Subtropical Southwestern Atlantic.

variations 29 young females (TL mean $=144 \pm 16 \mathrm{~mm}$ ) and 29 small young females (TL mean $=175 \pm 16 \mathrm{~mm}$ ).

The morphological classification of the otolith showed that some characteristics were constant along the ontogeny such as: absent rostrum and excisura, pseudo-ostial type of sulcus acusticus, the anterior region was round, the posterior region was peak and the external face had calcareous concretions at all class intervals (Fig. 5).

The length and height of the otolith and the ellipticity and SRS indices presented a positive and direct relationship with TL (Figs. 6A, B, G and $\mathrm{H}$ ). In contrast, the inverse was observed between $T L$ and the OL/TL aspect ratio, $\mathrm{OH} / \mathrm{OL} \%$ aspect ratio and the form factor
Table 1. Values of probability obtained through the Conover post-hoc test applied to Bonferroni correction between the class intervals and the morphometric indices and the length and height of the sagitta otolith of Menticirrhus americanus from a subtropical Southwestern Atlantic. Values $p<0.05$ and $\mathrm{p}<0.001$ were considered significant.

\begin{tabular}{cccccc}
\hline Class interval $(\mathrm{mm})$ & $110-150$ & $160-200$ & $210-250$ & $260-300$ & $310-350$ \\
\hline $160-200$ & $<0.0001$ & & & & \\
$210-250$ & $<0.0001$ & $>0.05$ & & & \\
$260-300$ & $<0.0001$ & $<0.0001$ & $<0.05$ & & \\
$310-350$ & $<0.0001$ & $>0.05$ & $>0.05$ & $>0.05$ & \\
\hline
\end{tabular}

(Figs. 6C, D and E). The rectangularity index showed a tendency to increase only for the intervals 110-150 and 160-200 mm, and this upward trend was not found in the upper intervals (Fig. 6F).

The Kruskal-Wallis test between the morphometric parameters $(\mathrm{OL}$ and $\mathrm{OH})$ and all shape indices between the class intervals indicated significant differences ( $p<0.001)$, suggesting ontogenetic variations along the growth of $M$. americanus. The Bonferroni correction of the Conover post-hoc test interactions are shown in Table 1.

In the Table 2, the morphometric parameters of the fish and otoliths analyzed together with the otolith shape indices, separated by sex and life stage. Due to size selection the averages of Table 2 are similar for both males and females and young females and small adult females.

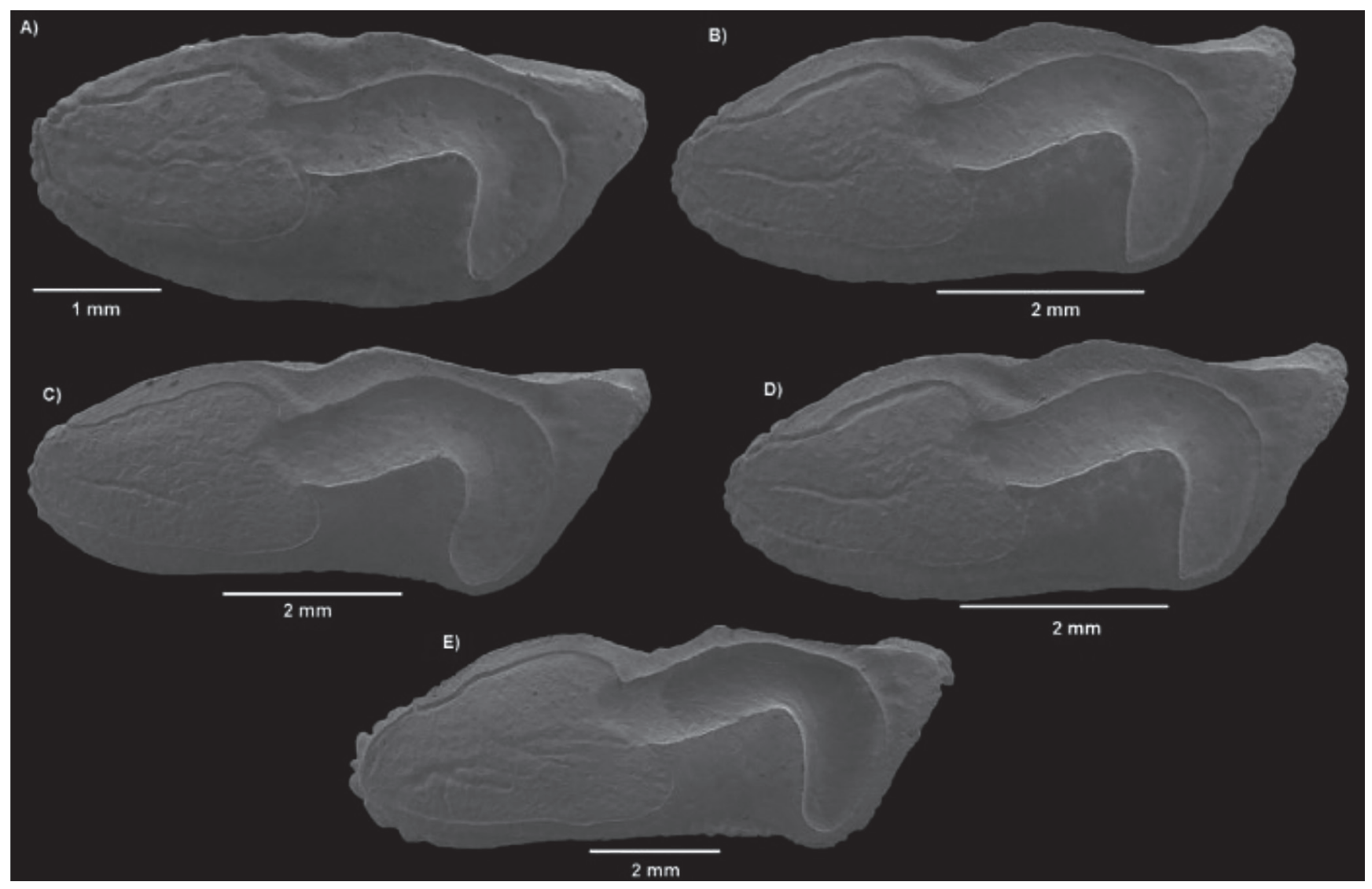

Figure 5. Micrograph of the inner face of the right sagitta otolith of Menticirrhus americanus throughout its ontogenetic development: (A) $132 \mathrm{~mm}$ interval 110-150 magnification 52x, (B) $169 \mathrm{~mm}$ interval 160-200 magnification 42x, (C) $214 \mathrm{~mm}$ interval 210-250 magnification 36x, (D) $285 \mathrm{~mm}$ interval 260-300 magnification 42x and (E) $333 \mathrm{~mm}$ interval 310-350 magnification 26x. 
The Wilcoxon Mann-Whitney test evidence significant differences ( $W=545, p=0.0002$ ) only for SRS between males and females. For small adult females and young females, the Wilcoxon Mann-Whitney test among all otolith parameters was significant $(p<0.005)$, except for
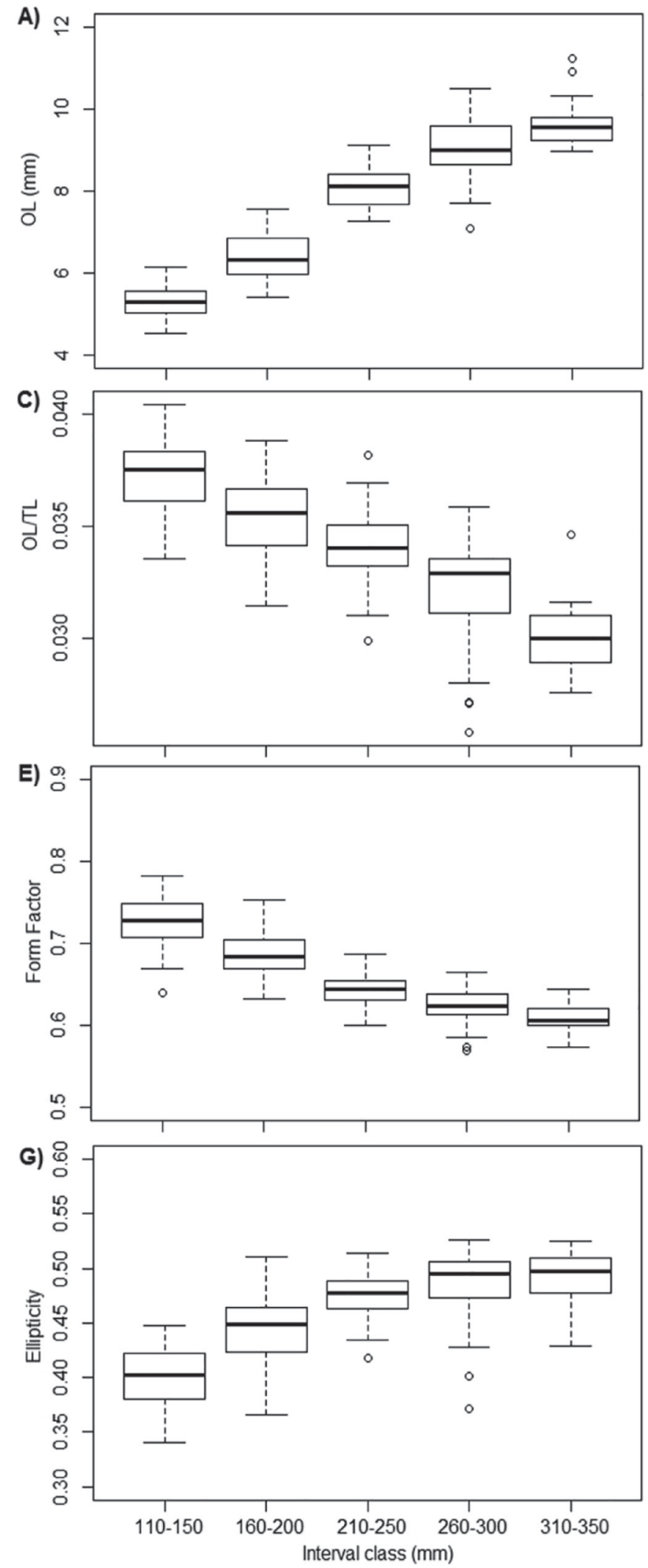

the rectangularity $(\mathrm{W}=546, \mathrm{p}=0.09)$ and $\mathrm{SRS}(\mathrm{W}=530$, $\mathrm{p}=0.15$ ) indices.

Reconstruction of the contour of the otoliths along the ontogeny showed a high variability in the contour between the different intervals (Fig. 8). From PERMANOVA,
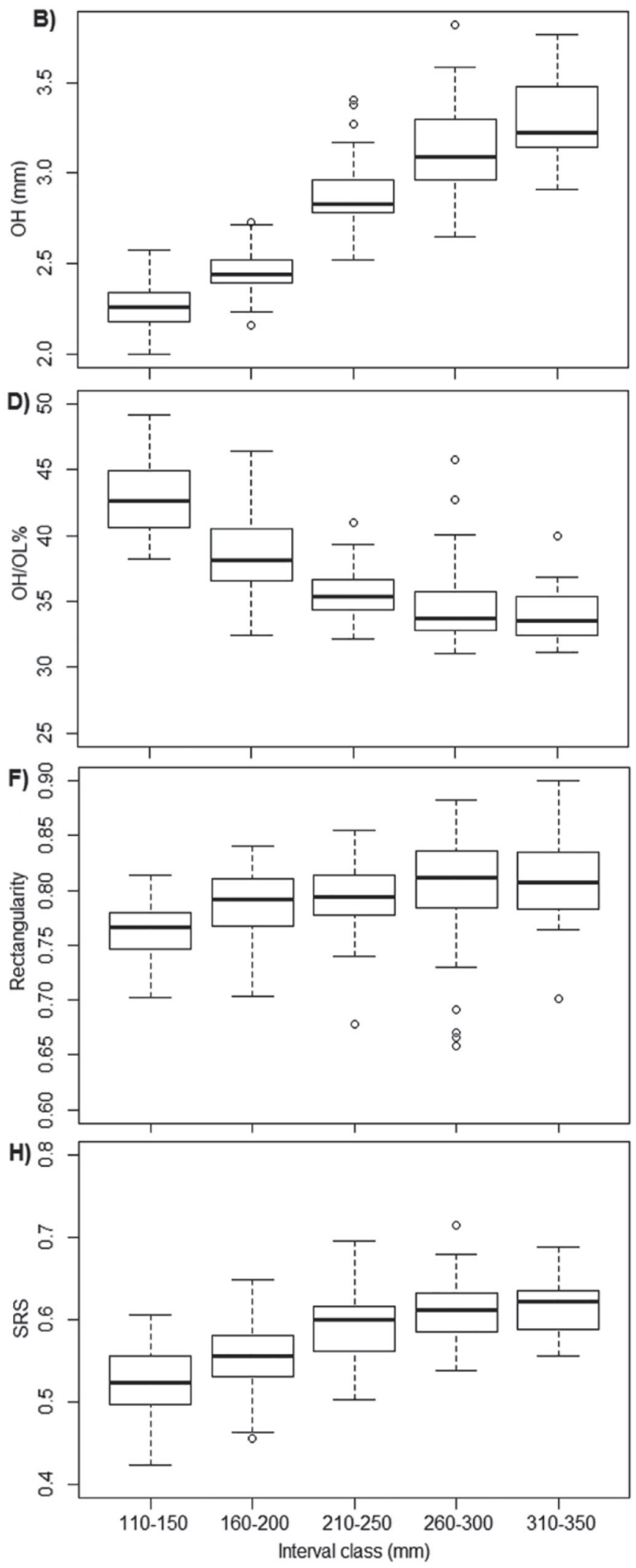

Figure 6. Box plot (mean and confidence interval) of morphometric parameters and morphometric indices of the otolith sagitta of Menticirrhus americanus per class interval: (A) otolith length (OL), (B) otolith height (OH), (C) OL/TL aspect ratio, (D) OH/OL\% aspect ratio, (E) form factor, (F) rectangularity, (G) ellipticity and (H) surface of the sulcus acusticus (SRS). Circles indicate outliers. 
Table 2. Morphometric parameters and shape indices (mean \pm standard deviation) of Menticirrhus americanus from a subtropical environment were: males $(M, n=30)$, females $(F, n=30)$, young females $(Y, n=29)$ and small females $(A, n=29)$.

\begin{tabular}{|c|c|c|c|c|c|c|c|c|c|}
\hline Sex & $\mathrm{TL}(\mathrm{mm})$ & $\mathrm{OL}(\mathrm{mm})$ & $\mathrm{OH}(\mathrm{mm})$ & 0L/TL & OH/OL\% & Form Factor & Rectangularity & Ellipticity & SRS \\
\hline$M$ & $222 \pm 16$ & $7.5 \pm 0.5$ & $2.7 \pm 0.2$ & $0.03 \pm 0.002$ & $36.0 \pm 0.01$ & $0.6 \pm 0.02$ & $0.8 \pm 0.02$ & $0.4 \pm 0.02$ & $0.6 \pm 0.04$ \\
\hline $\mathrm{F}$ & $230 \pm 12$ & $7.9 \pm 0.4$ & $2.8 \pm 0.1$ & $0.03 \pm 0.001$ & $35.2 \pm 0.01$ & $0.6 \pm 0.01$ & $0.8 \pm 0.02$ & $0.5 \pm 0.01$ & $0.6 \pm 0.03$ \\
\hline$Y$ & $144 \pm 16$ & $5.3 \pm 0.5$ & $2.3 \pm 0.1$ & $0.04 \pm 0.002$ & $43.1 \pm 0.02$ & $0.7 \pm 0.03$ & $0.8 \pm 0.02$ & $0.4 \pm 0.03$ & $0.5 \pm 0.04$ \\
\hline A & $176 \pm 15$ & $6.2 \pm 0.5$ & $2.4 \pm 0.1$ & $0.04 \pm 0.002$ & $39.2 \pm 3.0$ & $0.7 \pm 0.03$ & $0.8 \pm 0.03$ & $0.4 \pm 0.03$ & $0.5 \pm 0.04$ \\
\hline
\end{tabular}

Table 3. Values of probability obtained through the PERMANOVA with the Bonferroni correction applied in the contour of the Menticirrhus americanus otoliths among the class intervals. Values $p<0.05$ and $p<0.001$ were considered significant.

\begin{tabular}{cccccc}
\hline Class intervals $(\mathrm{mm})$ & $\mathbf{1 1 0 - 1 5 0}$ & $\mathbf{1 6 0 - 2 0 0}$ & $\mathbf{2 1 0 - 2 5 0}$ & $\mathbf{2 6 0 - 3 0 0}$ & $\mathbf{3 1 0 - 3 5 0}$ \\
\hline $160-200$ & $<0.001$ & & & & \\
$210-250$ & $<0.001$ & $<0.001$ & & & \\
$260-300$ & $<0.001$ & $<0.001$ & $<0.001$ & & \\
$310-350$ & $<0.001$ & $<0.001$ & $<0.05$ & $<0.001$ & \\
\hline
\end{tabular}

significant differences were detected between the contours of the class intervals $(F=3.32 ; p<0.0001)$. The Bonferroni test identified significant variation between all interactions (Table 3).

From the Fig. 7, there is a high variability of contour of the otoliths throughout their ontogeny. The otoliths distributed along PC1 tend to be rounded to elongated, being represented by the smaller intervals in the negative values of PC1 (interval class 110-150 and 160-200) and in the positive values of PC1 are distributed more elliptic otoliths represented by the range 260-300 with pointed posterior region. In PC2, there are the elongated, higher otoliths represented by the intervals 210-250 and 310-350 with a rounded posterior region (Fig. 7).

The CVA presented $98.6 \%$ of correct reclassification of the otoliths among the class intervals sampled (Table 4).
Table 4. Correct reclassification of the contour of the otolith Menticirrhus americanus among the class intervals obtained through the analysis of canonical variables (CVA). The number in parentheses corresponds to the frequency of reclassification.

\begin{tabular}{cccccc}
\hline Class intervals $(\mathbf{m m})$ & $\mathbf{1 1 0 - 1 5 0}$ & $\mathbf{1 6 0 - 2 0 0}$ & $\mathbf{2 1 0 - 2 5 0}$ & $\mathbf{2 6 0 - 3 0 0}$ & $\mathbf{3 1 0 - 3 5 0}$ \\
\hline $110-150$ & $30(100)$ & 0 & 0 & 0 & 0 \\
$160-200$ & 0 & $30(100)$ & 0 & 0 & 0 \\
$210-250$ & $2(6)$ & 0 & $28(94)$ & 0 & 0 \\
$260-300$ & 0 & 0 & 0 & $30(100)$ & 0 \\
$310-350$ & 0 & 0 & 0 & 0 & $19(100)$ \\
\hline Total & 32 & 30 & 28 & 30 & 19 \\
\hline
\end{tabular}

The contour of the otoliths of young and adult females shows a variability in the wavelet 1 , wavelet 4 , wavelet 5 and wavelet 6 (Fig. 9). The wavelets of males and females are distinguished mainly in the wavelet 4 (Fig. 10). With PERMANOVA, significant differences were identified between the contours of the sexes and life stages $(F=4.53$; $p=0.0031)$. The Bonferroni test identified significant variation between the sexes only (Table 5 ).

The PCA of contour of otoliths between sexes and stages of life demonstrates a high variability of shape of otoliths. Females have peak posterior region (Figs. 11A, C, D) and males have a more rounded posterior region (Fig. 11B). Young females and small young females present more rounded otoliths (Figs. 11C, D).
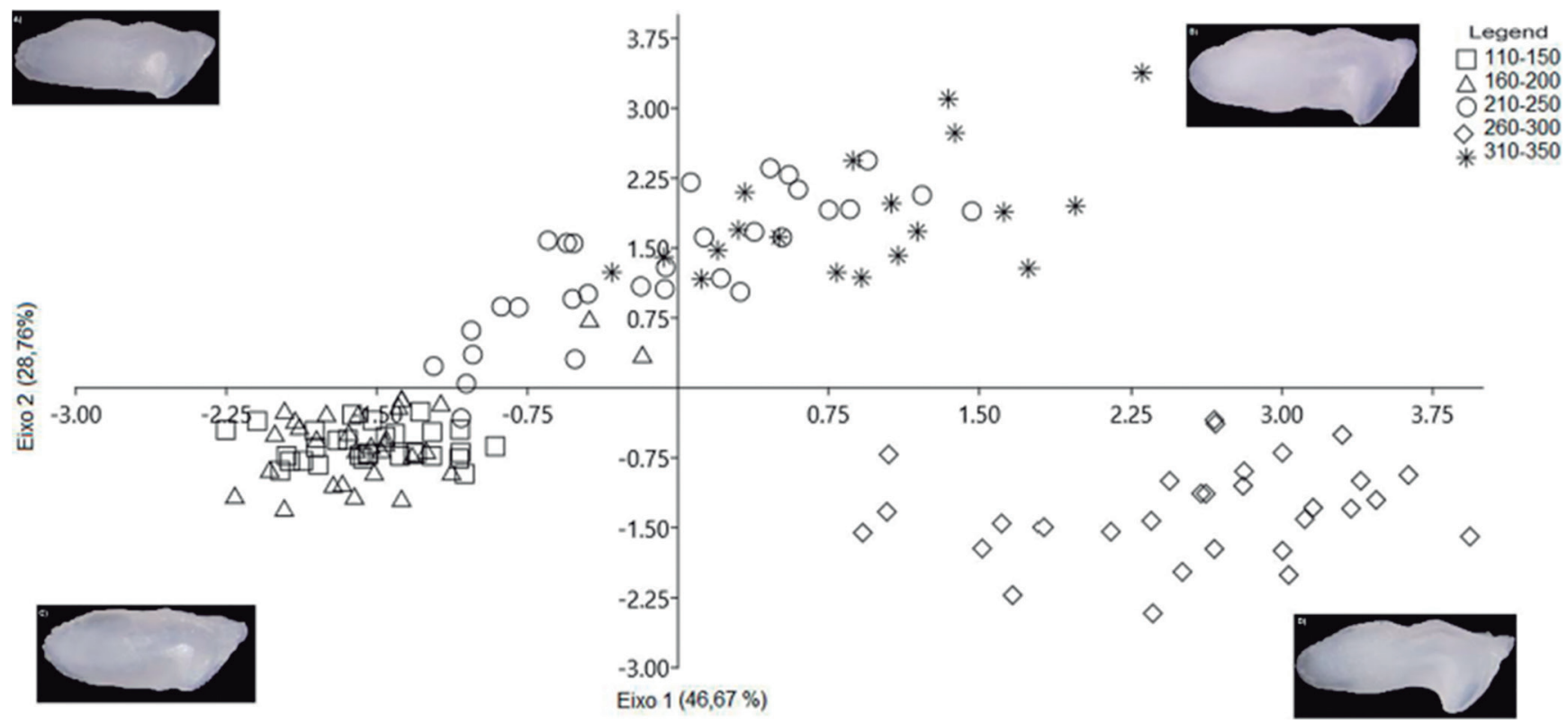

Figure 7. Scatterplot of the principal component analysis of the contour of the sagitta otolith of Menticirrhus americanus along its ontogeny sampled in two subtropical environments in the Southwestern Atlantic. 


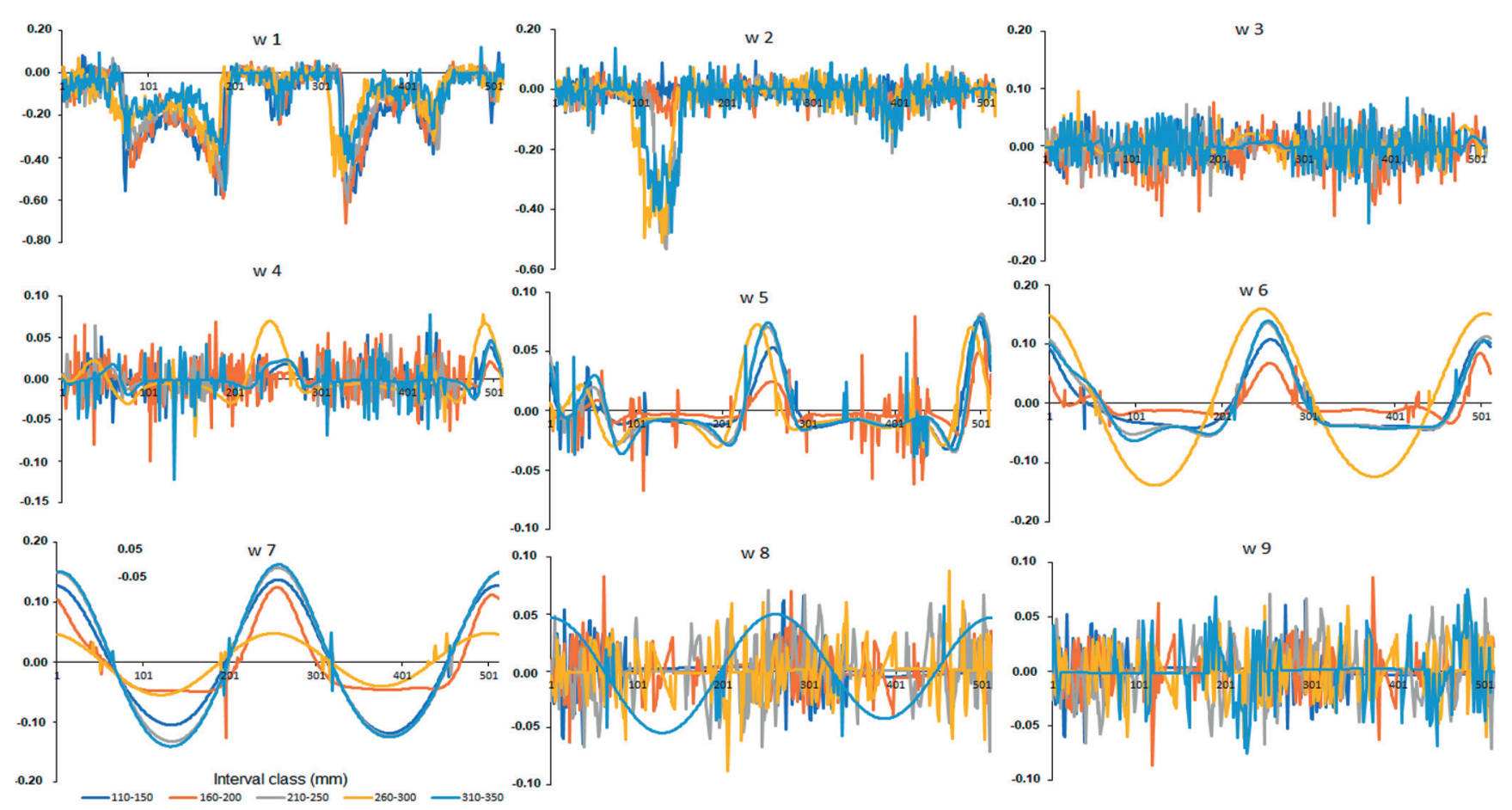

Figure 8. Decomposition of the contour of the sagitta otoliths throughout the ontogeny of Menticirrhus americanus, on the x-axis there are 512 Cartesian coordinates of the contour, $y$-axis, the means of the points. Interval class: dark blue 110-150 mm, orange 160-200 mm, grey 210-250 mm, yellow 260-300 mm and light blue 310-350 mm.

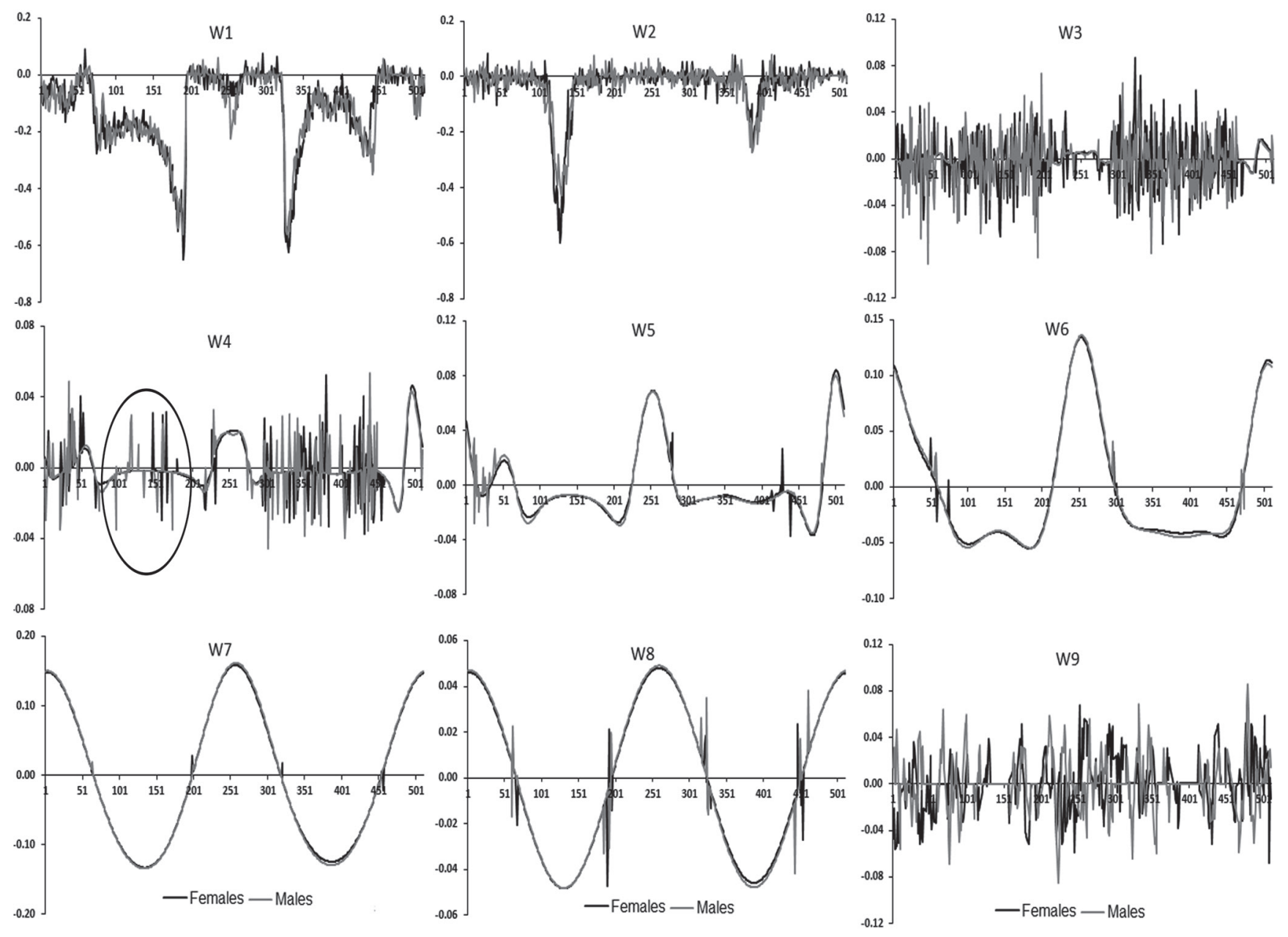

Figure 9. Decomposition of the contour of the sagitta otoliths of males and females of Menticirrhus americanus, on the x-axis there are 512 Cartesian coordinates of the contour, $y$-axis, the means of the points. Females are black lines and males are gray lines. Circle in wavelet 4 to highlight more discrepant region between males and females. 
Table 5. Values of probability obtained through the PERMANOVA with the Bonferroni correction applied in the contour of the Menticirrhus americanus otoliths among the sex ( $\mathrm{M}=$ males and $\mathrm{F}=$ females) and stage of life. Values $p<0.05$ and $p<0.001$ were considered significant.

\begin{tabular}{cccc}
\hline & F & M & Young \\
\hline $\mathrm{F}$ & & & \\
$\mathrm{M}$ & 0.01 & & \\
Young & 1 & 0.07 & \\
Small Females & 0.83 & 0.2 & 1 \\
\hline
\end{tabular}

The CVA presented $79.6 \%$ of correct reclassification of the otoliths between the sexes and life stages sampled. Young females and small young females had the highest correct percentage of classification (Table 6).

\section{DISCUSSION}

The morphological features of otoliths of M. americanus evaluated during their ontogenetic development, such as: absence of rostrum and excisura, heterosulcoid sulcus acusticus and round anterior region, can be considered diagnostic characteristics of this species, as also
Table 6. Correct reclassification of the contour of the otolith Menticirrhus americanus among the sex and stage of life obtained through the analysis of canonical variables (CVA). The number in parentheses corresponds to the frequency of reclassification.

\begin{tabular}{cccccc}
\hline & $\mathbf{F}$ & $\mathbf{M}$ & Young & Small Females & Total \\
\hline $\mathrm{F}$ & $21(72)$ & $6(21)$ & $1(3)$ & $1(3)$ & 29 \\
M & $10(33)$ & $19(63)$ & $1(3)$ & 0 & 30 \\
Young & 0 & 0 & $27(93)$ & 2 & 29 \\
Small Females & $1(3)$ & 0 & $2(7)$ & $27(90)$ & 30 \\
\hline Total & 32 & 25 & 31 & 30 & 118 \\
\hline
\end{tabular}

described in other studies (Volpedo \& Echeverría, 2000; Siliprandi et al., 2014; Volpedo et al., 2017).

The absence of rostrum and excisura indicates that $M$. americanus poorly uses water column to move, being a species associated with the substrate after the settlement. These characteristics of the otolith allow to differentiate $M$. americanus from species that use the water column, since these have a well-developed rostrum and excisura (Volpedo \& Echeverría, 2003; Carvalho et al., 2015).

The otolith of $M$. americanus showed ontogenetic variations in the same way as other authors observed

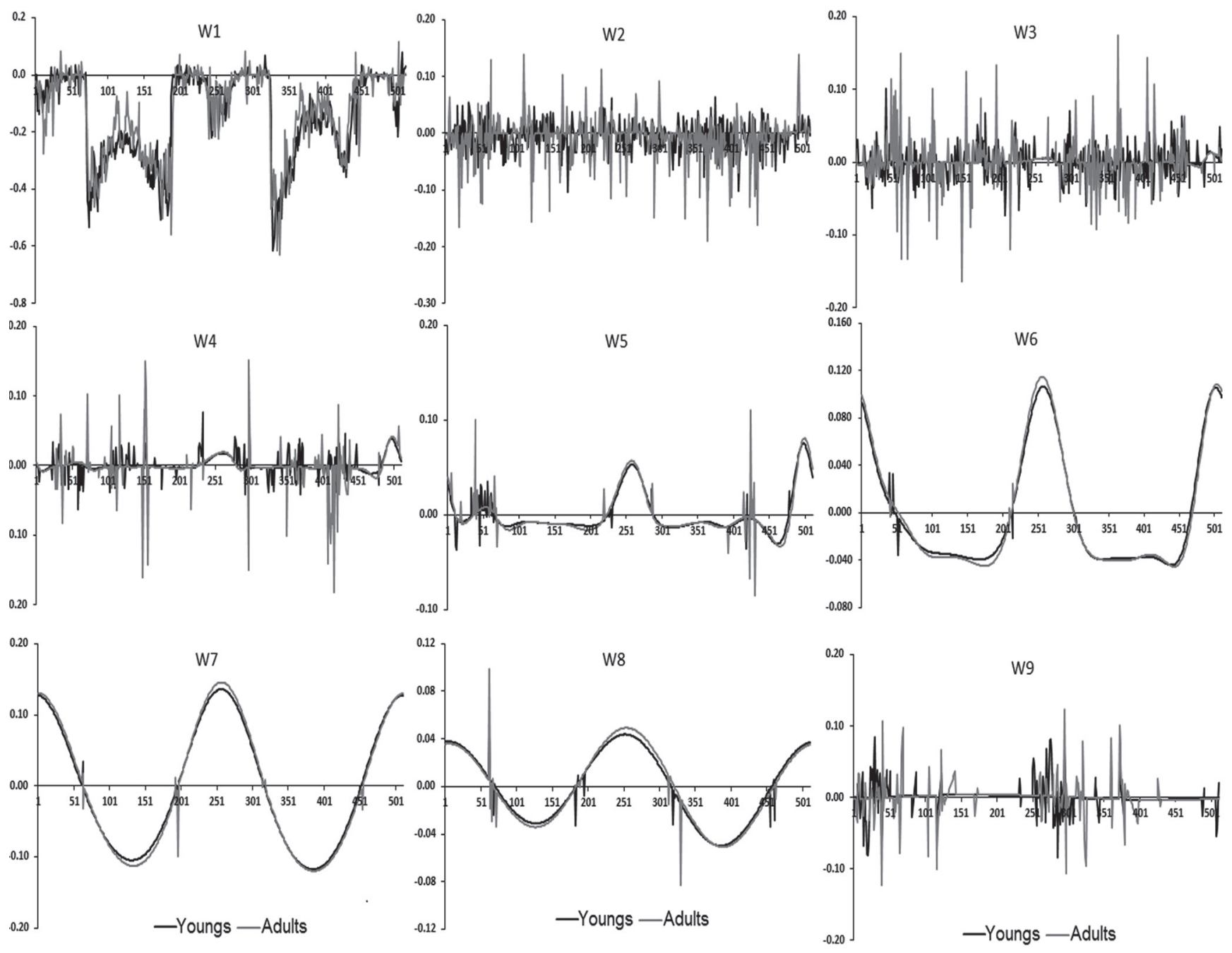

Figure 10. Decomposition of the contour of the sagitta otoliths of adult and young females of Menticirrhus americanus, on the $x$-axis there are 512 Cartesian coordinates of the contour, $y$-axis, the means of the points. Young females are the black lines and adult females, the gray lines. 


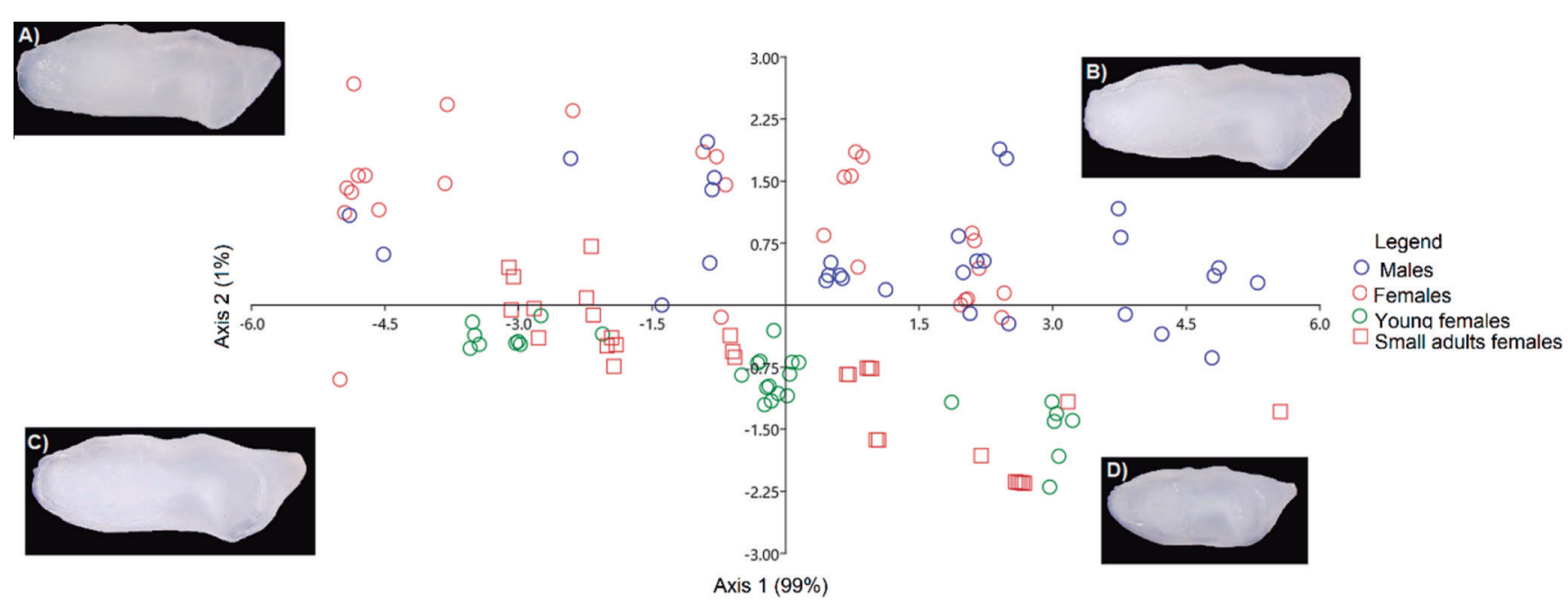

Figure 11. Scatterplot of the principal component analysis of the contour of the sagitta otolith of males (blue circles), females (red circles), young females (green square) Menticirrhus americanus in an estuarine beach of a subtropical environments in the Subtropical Southwestern Atlantic.

for other marine species (Volpedo \& Echeverría, 1999; Vignon, 2012; Carvalho et al., 2015). Menticirrhus americanus is a species of isometric positive growth $(b>3)$ (Dias et al., 2014; Froese \& Pauly, 2017), this characteristic is corroborated by the otolith growth change, which stops growing in the dorsoventral axis and begins to grow in the anteroposterior axis as also observed for Paralonchurus brasiliensis, another species belonging to the family Sciaenidae (Oliveira et al., 2009). According to Avigliano et al. (2012), elliptic otoliths are correlated with species that inhabit more saline environments, as is the case of the M. americanus otolith that has elliptic otoliths and has a preferential environment estuarine mouths and shallow internal shelf (Barletta et al., 2008).

Ontogenetic variations of otoliths indicate important characteristics of the ecology of $M$. americanus. According to Volpedo \& Echeverría (2003), values in the aspect ratio $(\mathrm{OH} / \mathrm{OL} \%)$ between 30 and 50 indicate species associated with unconsolidated substrates (composed of silt, clay and sand), the values of $M$. americanus for this index varied between 35 and 45, reflecting that this species throughout its ontogeny is associated with unconsolidated substrates. This preference of M. americanus during all stages of life for this type of substrate is corroborated by its presence in the accompanying fauna in the Atlantic seabob (Xiphopenaeus kroyeri) shrimp fishery (Bernardo et al., 2011; Cattani et al., 2011).

According to Volpedo et al. (2008), the SRS index describes how much of the otolith surface comes into contact with the macular nerve through the sulcus acusticus. From this relation, it is possible to suggest the auditory capacity of fish; M. americanus presented higher values of this index than species of the genus Cynoscion (Aguirre, 2003), suggesting a greater auditory capacity of M. americanus in relation to the species of this genus. These observed differences are the result of several ecological factors. First, species of the genus Cynoscion forage in the water column (Rondineli et al., 2007) requiring greater visual acuity and may have a lower auditory capacity, while M. americanus is a benthivorous species (Rondineli et al., 2007) associated with environments with higher turbidi- ty, thus requiring a greater auditory than visual capacity. Another factor is the detection of predators by hearing (Popper et al., 2005), as M. americanus is prey to several species of top predators, including marine mammals (Di Beneditto \& Siciliano, 2007; Bornatowski et al., 2014; Miotto et al., 2017) its keen hearing favors its escape. Finally, a greater auditory capacity facilitates intraspecific recognition for mating, essential for $M$. americanus that forms reproductive aggregates through vocalization (Ramcharitar et al., 2006).

Otoliths of males and females of $M$. americanus showed a sexual dimorphism in both the contour and the SRS index. The species of the family Sciaenidae are known to have the ability to vocalize, and this vocalization may be for defense of the territory or for reproduction (Montie et al., 2015). In some species, male and female vocalize, but in the reproductive age, males increase the intensity of vocalization (Tellechea et al., 2011; Parmentier et al., 2014). In addition to the behavioral differences, there is a morphological distinction in the size of the sound muscle between the sexes (Ramcharitar et al., 2006; Tellechea \& Norbis, 2012). The sexual dimorphism in otoliths of $M$. americanus may be a result of the need to capture sound since females are attracted to males for mating by their vocalization. Species that form reproductive aggregates become more susceptible to fishing in this period, causing impacts for future cuts to withdrawals from individuals able to spawn.

As well as $M$. americanus, other species of demersal fish have demonstrated sexual dimorphism in the sagitta otolith contour (Mille et al., 2015; Bose et al., 2016). However, the small number of studies that verify the existence or not of sexual dimorphism in the otoliths of demersal species makes it impossible to conclude that this is a characteristic of demersal fish.

Both shape indices and contour analysis demonstrated significant differences in otoliths between young females and small adult females of $M$. americanus. With these analyses, the influence of the reproductive process on the otolith shape of the females of $M$. americanus is confirmed by the reduction of energy invested in somat- 
ic growth for the formation of oocytes and a change in the rates of calcium deposition on the otolith, once this element is of great importance for oocyte formation.

From the results of this study it is possible to conclude that $M$. americanus presents an ontogenetic variation of the otolith shape. There is a sexual dimorphism between female and male otoliths, suggesting that these sexual variations are related to sound uptake into the formation of reproductive aggregates. Stages of life also showed differences in the shape of otoliths suggesting an influence of reproduction and somatic growth in this structure.

\section{ACKNOWLEDGMENTS}

The authors are grateful for funding from the project CAFP-BA/SPU and 292/14 UFPR/Fundação Araucária. They alsothankCONICET(PIP112-20120100543CO),Universidad de Buenos Aires (UBACYT 20020150100052BA), Agencia Nacional de Promoción Científica y Técnica (ANPCyT PICT 2015-1823); CNPQ for the PhD degree scholarship to the first author (CNPQ 141267/2015-1), LAFMA (CEM-UFPR) for the stereomicroscope and the Olympus DP71 camera and the Centro de Microscopia Eletrônica (CME-UFPR) for the micrographs. This study was financed in part by the Coordenação de Aperfeiçoamento de Pessoal de Nível Superior, Brasil (CAPES) - Finance Code 001.

\section{REFERENCES}

Aguirre, W.E. 2003. Allometric growth of the sulcus in Cynoscion spp. (Sciaenidae). Journal of Fish Biology, 63: 1341-1346.

Avigliano, E.; Comte, G.; Rosso, J.J.; Mabragaña, E.; Paola, D.R.; Sanchez, S.; Volpedo, A.; Rosso, F.D. \& Schenone, N.F. 2015. Identificación de stocks pesqueros de la corvina de río (Plagioscion ternetzi) de los ríos Paraguay y Paraná, mediante el análisis morfométrico de sus otólitos. Latin American Journal of Aquatic Research, 43(3): 718-725.

Avigliano, E.; Martinez, C.F.R. \& Volpedo, A.V. 2014. Combined use of otolith microchemistry and morphometry as indicators of the habitat of the silverside (0dontesthes bonariensis) in a freshwater-estuarine environment. Fisheries Research, 149: 55-60.

Avigliano, E.; Tombari, A. \& Volpedo, A.V. 2012. ¿EL otolito de pejerrey (Odontesthes bonariensis), refleja el estrés ambiental? Biología Acuática, 1-7.

Barletta, M.; Saint-Paul, U.; Amaral, C.S.; Corrêa, M.F.M.; Guebert, F.; Dantas, D.V. \& Lorenzi, L. 2008. Factors affecting seasonal variations in fish assemblages at an ecocline in a tropical-subtropical mangrove fringed estuary. Journal of Fish Biology, 73: 1314-1336.

Bernardo, C.; Spach, H.L.; Schwarz Junior, R.; Stoiev, S.B. \& Cattani, A.P. 2011. A captura incidental de cienídeos em arrasto experimental com rede-deportas utilizada na pesca do camarão-sete-barbas, Xiphopenaeus kroyeri, no estado do Paraná, Brasil. Arquivos de Ciências do Mar, 44: 98-105.

Bervian, G.; Fontoura, N.F. \& Haimovici, M. 2006. Statistical model of variable allometric growth: otolith growth in Micropogonias furnieri (Actinopterygii, Sciaenidae). Journal of Fish Biology, 68: 196-208.

Bornatowski, H.; Braga, R.R.; Abilhôa, V. \& Corrêa, M.F.M. 2014. Feeding ecology and trophic comparisons of six shark species in a coastal ecosystem off southern Brazil. Journal of Fish Biology, 85: 246-263.
Bose, A.P.H.; Adragna, J.B. \& Balshine, S. 2016. Otolith morphology varies between populations, sexes and male alternative reproductive tactics in a vocal toadfish Porichthys notatus. Journal of Fish Biology, 1-15.

Bustos, L.R.; Daneri, G.A.; Harrington, A.; Varela, E. \& Volpedo, A.V. 2012. The diet of the South American tarsea lion (Otaria flavescens) at Río Negro, Patagonia, Argentina, during the winter-spring period. Iheringia, Série Zoológica, 102: 394-340.

Capoccioni, F.; Costa, C.; Aguzzi, J.; Menesatti, P.; Lombarte, A. \& Ciccotti, E. 2011. Ontogenetic and environmental effects on otolith shape variability in three Mediterranean European eel (Anguilla anguilla, L.) local stocks. Journal of Experimental Marine Biology and Ecology, 397: 1-7.

Carvalho, B.M. \& Corrêa, M.F.M. 2014. Morphometry of the sagitta otolith from Atherinella brasiliensis (Quoy and Gaimard, 1824) (Actinopterygii: Atherinopsidae), at the coast of Paraná. Revista Tropical Oceanography, 42: 54-59.

Carvalho, B.M.; Vaz-dos-Santos, A.M.; Spach, H.L. \& Volpedo, A.V. 2015. Ontogenetic development of the sagitta otolith of the anchovy, Anchoa tricolor, in a subtropical estuary. Scientia Marina, 79: 409-418.

Carvalho, B.M.; Volpedo, A.V.; Vaz-dos-Santos, A.M. \& Spach, H.L. 2017. Use of otolith microchemistry as an indicator of the habitat of Anchoa tricolor (Spix \& Agassiz, 1829) in a subtropical estuary. Latin American Journal of Aquatic Research, 45: 457-465.

Cattani, A.P.; Santos, L.0.; Spach, H.L.; Budel, B.R. \& Gondim Guanais, J.H.D. 2011. Avaliação da ictiofauna da fauna acompanhante da pesca do camarão sete-barbas do município de Pontal do Paraná, litoral do Paraná, Brasil. Boletim do Instituto de Pesca, 37: 247-260.

Chao, N.L.; Frédou, F.L.; Haimovici, M.; Peres, M.B.; Polidoro, B.; Raseira, M.; Subirá, R. \& Carpenter, K. 2015. A popular and potentially sustainable fishery resource under pressure-extinction risk and conservation of Brazilian Sciaenidae (Teleostei: Perciformes). Global Ecology and Conservation, 1-10.

Corrêa, M.F.M. \& Viana, M.S. 1992. Catálogo dos otólitos sagitta de Sciaenidae (Ostheichthys - Perciformes) do litoral do estado do Paraná, Brasil. Nerítica, 7: 13-41.

Cruz, A. \& Lombarte, A. 2004. Otolith size and its relationship with colour patterns and sound production. Journal of Fish Biology, 65: 1512-1525.

Davoren, G.K. \& Halden, N.M. 2014. Connectivity of capelin (Mallotus villosus) between regions and spawning habitats in Newfoundland inferred from otolith chemistry. Fisheries Research, 159: 95-104.

Di Beneditto, A.P.M. \& Siciliano, S. 2007. Stomach contents of the marine tucuxi dolphin (Sotalia guianensis) from Rio de Janeiro, south-eastern Brazil. Journal of the Marine Biological Association of the United Kingdom, 87: 253-254.

Dias, J.F.; Fernandez, W.S. \& Schmidt, T.C.S. 2014. Length-weight relationship of 73 fish species caught in the southeastern inner continental shelf region of Brazil. Latin American Journal of Aquatic Research, 42: 127-136.

Egbert, M.E. \& Rulifson, R.A. 2017. Age and growth, reproductive biology, and histology in Atlantic needlefish (Strongylura marina) in a coastal freshwater lake. Marine and Freshwater Research, 68(7):1325-1335.

Froese, R. \& Pauly, D. 2017. FishBase. World Wide Web electronic publication. www.fishbase.org, version 06/2017.

Gagliano, M. \& McCormick, M.I. 2004. Feeding history influence otolith shape in tropical fish. Marine Ecology Progress Series, 278: 291-296.

Haluch, C.F.; Freitas, M.0.; Corrêa, M.F.M. \& Abilhoa, V. 2009. Variação sazonal e mudanças ontogênicas na dieta de Menticirrhus americanus (Linnaeus, 1758) (Teleostei, Sciaenidae) na baía de Ubatuba-Enseada, Santa Catarina, Brasil. Pan-American Journal of Aquatic Sciences, 4: 347-356.

Hammer, Ø.; Harper D.A.T. \& Ryan, P.D. 2001. Past: Paleontological Statistics Software Package for Education and Data Analysis. Palaeontologia Electronica, 4: 1-9. 
Légua, J.; Plaza, G.; Pérez, D. \& Arkhiphin, A. 2013. Otolith shape analysis as a tool for stock identification of the southern blue whiting, Micromesistius australis. Latin American Journal of Aquatic Research, 41: 479-489.

Libungan, L.A.; Óskarsson, G.J.; Slotte, A.; Jacobsen, J.A. \& Pálsson, S. 2015. Otolith shape: a population marker for Atlantic herring Clupea harengus. Journal of Fish Biology, 86:1377-1395.

Linde, M.; Palmer, M. \& Gomez-Zurita, J. 2004. Differential correlates of diet and phylogeny on the shape of the premaxilla and anterior tooth in sparid fishes (Perciformes: Sparidae). Journal of Evolutionary Biology, 17: 941-952.

Lombarte, A. 1992. Changes in otolith area: sensory area ratio with body size and depth. Environmental Biology of Fishes, 33: 405-410.

Lombarte, A. \& Lleonart, J. 1993. Otolith size changes related with body grotwh, habitat depth and temperature. Environmental Biology of Fishes, 37: $297-306$

Lombarte, A. \& Tuset, V.M. 2015. Morfolmetria de otólitos. In: Volpedo \& Vaz-dos-Santos. Métodos de estudos com otólitos: princípios e aplicações. Buenos Aires, CAFP-BA-PIESCI. p. 59-91.

Mallat, S. 1991. Zero crossings of a wavelet transform. IEEE Transaction on Information Theory, 37(4): 1019-1033.

Mille, T.; Mahe, K.; Villanueva, M.C.; De Pontual, H. \& Ernande, B. 2015. Sagitta otolith morphogenesis asymmetry in marine fishes. Journal of Fish Biology, 87: 646-663.

Miotto, M.; Carvalho, B.M. \& Spach, H.L. 2017. Does the closed fishing season influence the ichthyofauna consumed by Larus dominicanus? Brazilian Journal Oceanography, 65: 9-18.

Monteiro, L.R.; Di Beneditto, A.P.M.; Guillermo, L.H. \& Rivera, L.A. 2005. Allometric changes and shape differentiation of sagitta otoliths in sciaenid fishes. Fisheries Research, 74: 288-299.

Montie, E.W.; Vega, S. \& Powell, M. 2015. Seasonal and spatial patterns of fish sound production in the May River, South Carolina. Transactions of the American Fisheries Society, 144: 705-716.

Oliveira, M.A.; Di Beneditto, A.P.M. \& Monteiro, L.R. 2009. Variação geográfica na forma e nas relações alométricas dos otólitos sagitta da maria-luiza Paralonchurus brasiliensis (Steindachner, 1875) (Teleostei, Sciaenidae) no litoral norte do Rio de Janeiro (21 $\left.{ }^{\circ} \mathrm{S}-23^{\circ} \mathrm{S}\right)$, Brasil. Boletim do Instituto de Pesca, 35: 3 475-485.

Parisi-Baradad, V.; Manjabacas, A.; Lombarte, A.; Olivella, R.; Chic, 0.; Piera, J. \& García-Ladona, E. 2010. Automatic Taxon Identification of Teleost fishes in an otolith online database. Fisheries Research, 105: 13-20.

Parmentier, E.; Tock, J.; Falguiére, J.C. \& Beauchaud, M. 2014. Sound production in Sciaenops ocellatus: Preliminary study for the development of acoustic cues in aquaculture. Aquaculture, 432: 204-211.

Pohlert, T. 2016. The Pairwise Multiple Comparison of Mean Ranks Package (PMCMR). R package. http://CRAN.R-project.org/package=PMCMR.

Popper, A.N.; Ramcharitar, J. \& Campana, S.E. 2005. Why otoliths? Insights from inner ear physiology and fisheries biology. Marine and Freshwater Research, 56: 497-504.

Possamai, B. \& Fávaro, L.F. 2015. Using mariculture as a breeding site: reproduction of Hypleurochilus fissicornis (Actinopterygii: Blenniidae). Scientia Marina, 79: 1-10.

Ramcharitar, J.; Gannon, D.P. \& Popper, A.N. 2006. Bioacoustics of Fishes of the Family Sciaenidae (Croakers and Drums. Transactions of the American Fisheries Society, 135: 1409-1431.

Rondineli, G.R.; Braga, F.M.S.; Tutui, S.L.S. \& Bastos, G.C.C. 2007. Dieta de Menticirrhus americanus (Linnaeus, 1758) e Cynoscion jamaicensis (Vaillant e Bocourt, 1883) (Pisces, Sciaenidae) no sudeste do Brasil, Estado de São Paulo. Boletim do Instituto de Pesca, 33: 221-228.

Sadighzadeh,Z.;Tuset, V.M.;Valinassab, T.;Dadpour, M.R.\&Lombarte, A. 2012. Comparison of different otolith shape descriptors and morphometrics for the identification of closely related species of Lutjanus spp. from the Persian Gulf. Marine Biology Research, 8: 802-814.

Sadighzadeh, Z.; Valinassa, T.; Vosugi, G.; Motallebi, A.A.; Fatemi, M.R.; Lombarte, A. \& Tuset, V.M. 2014. Use of otolith shape for stock identification of John's snapper, Lutjanus johnii (Pisces: Lutjanidae), from the Persian Gulf and the Oman Sea. Fisheries Research, 155: 59-63.

Siliprandi, C.C.; Rossi-Wongtschowski, C.L.D.B.; Brenha, M.R.; Gonsales, S.A.; Santificetur, C. \& Vaz-Dos-Santos, A.M. 2014. Atlas of marine bony fish otoliths (sagittae) of southeastern - southern Brazil Part II: Perciformes (Carangidae, Sciaenidae, Scombridae and Serranidae). Brazilian Journal Oceanography, 62: 28-101.

Spalding, M.D.; Fox, H.E.; Allen, G.R.; Davidson, N.; Ferdaña, Z.A.; Finlayson, M.; Halpern, B.S.; Jorge, M.A.; Lombana, A.; Lourie, S.A.; Martin, K.D.; Mcmanus, E.; Molnar, J.; Recchia, C.A. \& Robertson, J. 2007. Marine Ecoregions of the World: A Bioregionalization of Coastal and Shelf Areas. BioScience, 57: 573-584.

Tanner, S.E.; Reis-Santos, P.; Vasconcelos, R.P.; Fonseca, V.F.; França, S.; Cabral, H.N. \& Thorrold, S.R. 2013. Does otolith geochemistry record ambient environmental conditions in a temperate tidal estuary? Journal of Experimental Marine Biology and Ecology, 441: 7-15.

Teimori, A.; Jawad, L.A.J.; Al-Kharusi, L.H.; Al-Mamry, J.M. \& Reichenbacher, B. 2012. Late Pleistocene to Holocene diversification and historical zoogeography of the Arabian killifish (Aphanius dispar) inferred from otolith morphology. Scientia Marina, 76: 637-645.

Tellechea, J.S. \& Norbis, W. 2012. Sexual Dimorphism in Sound Production and Call Characteristics in the Striped Weakfish Cynoscion guatucupa. Zoological Studies, 51: 946-955.

Tellechea, J.S.; Norbis, W.; Olsson, D. \& Fine, M.L. 2011. Calls of the black drum (Pogonias cromis: Sciaenidae): geographical differences in sound production between northern and southern hemisphere populations. Journal of Experimental Zoology, 315: 48-55.

Tombari, A.D.; Volpedo, A.V. \& Echeverría, D.D. 2005. Desarrollo de la sagitta en juveniles y adultos de Odontesthes argentinensis (Valenciennes, 1835) y 0. bonariensis (Valenciennes, 1835) de la provincia de Buenos Aires, Argentina (Teleostei: Atheriniformes). Revista Chilena de História Natural, 78: 623-633.

Torres, G.J.; Lombarte, A. \& Morales-Nin, B. 2000. Variability of the sulcus acusticus in the sagitta otolith of the genus Merluccius (Merlucciidae). Fisheries Research, 46: 5-13.

Tuset, V.M.; Lombarte, A.; Assis, C.A. 2008. Otolith atlas for the western Mediterranean, north and central eastern Atlantic. Scientia Marina, 72: 7-198.

Tuset, V.M.; Lozano, I.J.; Gonzalez, J.A. 2003. Shape indices to identify regional differences in otolith morphology of comber, Serranus cabrilla (L., 1758). Journal of Applied Ichthyology, 19: 88-93.

Tuset, V.M.; Imondi, R.; Aguado, G.; Otero-Ferrer, J.L.; Santschi, L.; Lombarte, A. \& Love, M. 2015. Otolith Patterns of Rockfishes from the Northeastern Pacific. Journal of Morphology, 276: 458-469.

Vaz-dos-Santos, A.M. \& Rossi-Wongtschwski, C.L.D.B. 2007. Age and growth of the Argentine hake Merluccius hubbsi Marini, 1933 in the Brazilian SouthSoutheast Region during 1996-2001. Neotropical Ichthyology, 3: 375-386.

Vignon, M. 2012. Ontogenetic trajectories of otolith shape during shift in habitat use: Interaction between otolith growth and environment. Marine Ecology Progress Series, 411: 231-241.

Volpedo, A.V. \& Echeverría, D.D. 1999. Morfología de los otolitos sagittae de juveniles y adultos de Micropogonias furnieri (Desmarest, 1823) (Sciaenidae). Revista Ciências Marina Thalassas, 15: 19-24.

Volpedo, A.V. \& Echeverría, D.D. 2000. Catálogo y claves de otolitos para la identificación de peces del Mar Argentino. Buenos Aires, Editorial Dunken. 90p. 
Volpedo, A.V. \& Echeverría, D.D. 2003. Ecomorphological patterns of the sagitta in fish on the continental shelf off Argentine. Fisheries Research, 60: 551-560.

Volpedo, A.V.; Biolé, F.G.; Callicó, Fortunato, R.G.; Tombari, A.D. \& Thompson, G.A. 2018. Otolitos de peces de la costa bonaerense. In: Volpedo, A.V.; Thompson, G.A. \& Avigliano, E. Atlas de otólitos de peces de Argentina. Buenos Aires, CAFP-BA-PIESCI. p. 181-248.

Volpedo, A.V.; Thomposn, G.A. \& Avigliano, E. 2017. Atlas de Otolitos de peces de Argentina. Buenos Aires, CAFP-BA-PIESCI. 321p.
Volpedo, A.V.; Tombari, A.D. \& Echeverría, D.D. 2008. Eco-morphological patterns of the sagitta of Antarctic. Polar Biology, 31: 1-6.

Waessle, J.A.; Lasta, C.A. \& Favero, M. 2003. Otolith morphology and body size relationships for juvenile Sciaenidae in the Río de la Plata estuary (35-36º S). Scienta Marina, 67: 233-240.

Zischke, M.T.; Litherland, L.; Tilyard, B.R.; Strarford, N.J.; Jones, E.L. \& Wang, Y.G. 2016. Otolith morphology of four mackerel species (Scomberomorus spp.) in Australia: Species differentiation and prediction for fisheries monitoring and assessment. Fisheries Research, 176: 39-47. 